\title{
Yield and Carrying Capacity of Meadows in Albania
}

\author{
Luan Hajno · Fiqiri Tahiri
}

received / primljeno: 20.08.2010. revised / prerađeno: 06.12.2010. accepted / prihvaćeno: 27.12.2010. (C) 2011 IFVC

\begin{abstract}
Summary: This study was carried out during 2003-2005 and included total meadow surface of 32,000 ha from seven regions throughout Albania (summer meadows of Shishtavec, Gramoz, Çajup, Lenie, Progonat, and winter meadows of Heremec-Delvine and Dukaj). The results of the study showed that average dry matter yield of the summer meadows is low (about $0.6 \pm 0.14 \mathrm{t} \mathrm{ha}^{-1}$ ) ranging from $0.33 \pm 0.07 \mathrm{t} \mathrm{ha}^{-1}$ to $0.53 \pm 0.10 \mathrm{t} \mathrm{ha}^{-1}$ at poor meadows (Progonat, Cajup, Lenie) and from $0.9 \pm 0.17 \mathrm{t} \mathrm{ha}^{-1}$ to $0.95 \pm 0.18 \mathrm{tha}^{-1}$ at rich meadows (Gramoz, Shistavec). Dry matter yield of the winter meadows ranged from $0.45 \pm 0.17 \mathrm{t} \mathrm{ha}^{-1}$ (Dukaj) to $0.57 \pm 0.13 \mathrm{t} \mathrm{ha}^{-1}$ (Heremec-Delvine). Regarding the rate of herbaceous biomass utilization in general, the plots closer to the villages were overstocked, which put high pressure on meadows resulting in their degradation. The coefficient of herbaceous phytomass utilization was about $94-95 \%$ at Lenia's meadows and a few other meadows close to villages. At a few plots of meadows (Lenia, Gramoz, Shishtavec) situated away from villages and at high sea level, the coefficient of meadow utilization reached 50-60\%. Energetic value expressed by starch unit (SU) depends on the flora and environmental conditions. According to laboratory analyses, the meadows of Dukaj had the highest energetic values (about $1.16 \pm 0.22 \mathrm{SU} \mathrm{kg}^{-1} \mathrm{dry}$ matter) while Lenia' meadows had the lowest energetic values (about $0.84 \pm 0.16 \mathrm{SU} \mathrm{kg}^{-1} \mathrm{dry}$ matter).
\end{abstract}

Keywords: capacity of meadow, sample, small ruminants, plot, region, dry matter yield

\section{Introduction}

Albania has a total surface area of 2,844,800 ha. According to the official agricultural statistical data (2005), a large part $(36 \%)$ of this area is classified as forests, which includes not only high and coppice forests, but also shrub lands. The second major land use are arable lands (24\%) where herbaceous crops and trees are grown. The third major land use are pastures, which are largely uncultivated areas covered mainly by herbaceous vegetation and small shrubs.

Pastures and meadows are distributed throughout the country and divided in two groups depending on the season of grazing: winter and summer ones. The latter include all the pastures found in the subalpine and alpine zones and amount to about 61\% of the whole area (Shundi \& Buzi 1991).

Dominant herbaceous species in the winter pastures are several annual grasses and legumes as well as perennials such as Dactylis glomerata, Festuca ovina, Poa bulbosa and Lolium perenne; while in the summer pastures only perennial species can be found, such as Poa pratensis, Phleum montanum, Nardus stricta, Trifolium

L. Hajno $(\varangle) \cdot$ F. Tahiri

Center for Agricultural Technology Transfer, Fushe-Kruje, Albania e-mail:1_hajno@yahoo.it alpestre, T. repens, etc. The productivity of pastures depends on several factors including the ecological zone they are found in, the physical characteristics and the grazing history. In these meadows, the phytomass production in a favourable year reaches $4 \mathrm{t} \mathrm{ha}^{-1}$ and in an unfavourable year (without sufficient rain) it decreases to $2 \mathrm{t} \mathrm{ha}^{-1}$. Although the provisions of the Pastures and Meadows' Law are technically and scientifically correct and constitute a sound basis for rational management of the pasture resources, very few of these provisions have actually been implemented.

Practically, there is no control over grazing management and very few state pastures and meadows have been rented to individuals or companies. As a result, the condition of pastures and meadows is poor to a large extent due to (a) large amount of unpalatable plant species or weeds, both herbaceous (e.g. Asphodelus microcarpus, Urginea maritima, etc) and woody (e.g. Phlomis fruticosa, Rubus sp., etc); (b) a large portion of bare soil on pastures and (c) a conspicuous accelerated erosion. The latter phenomenon is widespread in the pastures of the whole country, often accompanied by landslides, especially in the areas of flysch or marls.

Acknowledgements: Authors would like to thank NSRBA which supported this study. 
Gilles et al. (1981) reported that one of the causes of desertification is overgrazing by domestic animals. Many range managers have also argued that the lack of privately owned pastures is a major cause of overgrazing.

Carrying capacity in its most basic definition determines the maximum livestock that an ecosystem can support on a sustainable basis. Livestock carrying capacity is based on the idea of "ecological carrying capacity" under which populations grow until restricted feed supplies decrease birth rates and increase death rates. This point is defined as " $K$ " the asymptote of the population growth curve based on the available resources. The dominant range model based on the carrying capacity concept developed assumes that pastoralists occupy potentially equilibrial grazing systems. Destabilization of these systems is caused by overstocking. Carrying capacity is calculated from an estimate of annual production of consumable vegetation, linked to animal requirements for feed and nutrients. Annual primary production can be estimated (i) by the measurement of standing biomass (normally at the end of the growing season) or (ii) by remote sensing or (iii) predicted by using empirical relationships of primary productivity to rainfall or (iv) from more complex relationships of primary productivity to rainfall or (v) from more complex relationship between soils, soil water, fertility and rainfall. These estimates are normally corrected for the available or useful biomass, which is the proportion of the vegetation actually useable by livestock (grazing efficiency). Different types of livestock have different dietary preferences, grazing habits and efficiency. "Proper use" will vary according to growing conditions, species composition and the type of herbivore (Bartels et al. 1993, Sinsin 1993, Kussela et al. 2002, Macdonald et al. 2008).

Steenenkamp et al. (1995) reported that the integrated system for plant dynamics (ISPD) can serve as a basis for range condition and grazing capacity assessments.

The definition of carrying capacity as the maximum stocking rate possible without including damage to vegetation or related resources is clear and unambiguous. It is the range manager's task to balance the regeneration of the plants and the grazing pressure (Hobbs et al. 1985, Roe 1997).

Meadows constitute the main feed base for small ruminants, and in fact the meadows meet $75 \%$ of small ruminants' requirements in Albania. The evaluation of meadow yield is one of the key elements for the assignment of grazing capacity and stocking rate in order to provide sustainable management. Such assessments could help to establish a proper balance among meadow yield, livestock and land.

The objectives of this study were to assess average dry matter yield $\left(t \mathrm{tha}^{-1}\right)$, coefficient of phytomass utilization, dry matter content and energetic value (SU) of herbaceous mass, growth rate of standing biomass and optimum period of grazing (from beginning to the end of grazing).

\section{Materials and Methods}

Winter and summer meadows amount to 32,000 ha and these were divided into 334 plots (the size 100 ha per plot) in order to evaluate the yield. Winter meadows (Heremec-Delvine, Dukaj) are located on the lowlands and are grazed during winter (also including spring and autumn). Summer pastures (Shishtavec, Gramoz, Çajup, Lenie, Progonat) are located on the mountains and are grazed during summer for 4-6 months (MayOctober). Total of 677 samples randomly chosen from 334 plots served as tested surfaces (the size of tested surface was $4 \mathrm{~m}^{2}$ ), which means there were 2.1 tested surfaces for each plot. These tested surfaces were harvested for three consecutive years in order to evaluate their dry matter yield $\left(t \mathrm{ha}^{-1}\right)$ and energetic values (expressed in starch unit).

Number of samples of residues after grazing was 677, which were used to calculate the coefficient of the herbaceous mass utilization. The coefficient of phytomass utilization by livestock was calculated in this manner: yield minus residues after livestock grazing. For this purpose, harvesting of residues after grazing was carried out close to each of the tested surfaces. Dry matter yield was estimated per useful surface, which is actually meadow surface covered with herbaceous mass and available for grazing by livestock.

Total of 45 plots for every $100 \mathrm{~m}$ of altitude were used to define cycles of grazing and to estimate herbages growth rate for three years (growth rate $=$ final phytomass $(\mathrm{kg})$ - initial phytomass $(\mathrm{kg}) /$ time interval (days)). Every year, 800 samples were analyzed for each plot in order to estimate dry matter intake and energetic value $\mathrm{SU} \mathrm{kg}{ }^{-1}$ of dry matter. Dry mater content and energetic value of meadow phytomass were estimated by the Laboratory of Livestock Research Institute (IKZ), Tirana-Albania. Data were processed by employing ANOVA.

\section{Results and Discussions}

Results of the study showed that average yield of summer meadows was $0.6 \mathrm{t} \pm 0.14 \mathrm{t} \mathrm{ha}^{-1}$ which is 
generally considered low (Tab. 1). Dry matter yields ranged from 0.33 to $0.53 \mathrm{t} \mathrm{ha}^{-1}$ for poor meadows (Proganat, Çajup, Lenie) and 0.90 to $0.95 \mathrm{t} \mathrm{ha}^{-1}$ on average for rich meadows (Gramoz, Shishtavec).

The rate of herbaceous biomass utilization by livestock for all the regions is shown in table 2, togetherwith the assessment of yield and energetic value of meadows biomass. The data showed that plots close to villages were overstocked and had the highest consumption of fresh grass by livestock per unit surface. This high pressure on meadows has caused their degradation.

Plots no. 16 and 17 of Lenia region and plots no. 46 and 47 of Gramoz region that were close
There was no sound management of meadows in relation to the techniques of grazing. The grazing of some meadows was delayed, meaning that livestock came to graze at the time when grass has begun to flower and some meadow plants have reached the phase of low eating or they were inedible. In springtime, absence of proper ratio between intensive growth of meadow plants and ample grazing livestock was observed. The same phenomenon, caused by incomplete utilization of herbaceous biomass, was reported by Sinsin (1993) and within our study this occurred in some plots of HemerecDelvine, Dukaj and Gramoz meadows.

Table 1. Meadows dry matter yield $\left(\mathrm{tha}^{-1}\right)$ for the whole surface

Tabela 1. Prinos suve materije livada $\left(\mathrm{t} \mathrm{ha}^{-1}\right)$ za ukupnu površinu

\begin{tabular}{|c|c|c|c|c|}
\hline $\begin{array}{l}\text { Regions } \\
\text { Regioni }\end{array}$ & ha & $\begin{array}{l}\text { Whole surface } \\
\text { total dry matter } \\
\text { yield } \\
\text { ukupni prinos suve } \\
\text { materije }(\mathrm{t})\end{array}$ & xupna površ & $\begin{array}{l}\text { CV } \\
(\%)\end{array}$ \\
\hline Shishtavec & 2,902 & 2756.90 & $0.95 \pm 0.18$ & 18.9 \\
\hline Gramoz & 4,822 & 4339.80 & $0.90 \pm 0.14$ & 15.5 \\
\hline Çajup & 3,608 & 1804.00 & $0.50 \pm 0.13$ & 26.0 \\
\hline Lenie & 5,038 & 2670.14 & $0.53 \pm 0.10$ & 18.8 \\
\hline Progonat & 5,846 & 1929.18 & $0.33 \pm 0.07$ & 21.2 \\
\hline Heremec-Delvine & 5,470 & 3227.30 & $0.59 \pm 0.11$ & 16.9 \\
\hline Dukaj & 3,200 & 1536.00 & $0.48 \pm 0.88$ & 18.3 \\
\hline
\end{tabular}

to villages had a coefficient of herbaceous biomass utilization of 94-95\% while plots no. 37 and 38 in Lenia, no. 10 and 11 in Gramoz, no. 6, 7, 9, 10 in Shishtavec that were situated at higher altitudes and further away from villages had a rate of phytomass utilization about 50-60\%. Similar results were reported by Bartles et al. (1993) and Roe (1997).
As for energetic value content of herbages, the meadows of Dukaj had the highest energetic values $\left(1.16 \pm 0.22 \mathrm{SU} \mathrm{kg}^{-1}\right.$ dry matter) and Lenia' meadows had the lowest energetic values (0.84 $\pm 0.16 \mathrm{SU} \mathrm{kg}^{-1}$ dry matter).

In some cases, low yield of meadows is as a result of earlier grazing by livestock before plants reach

Table 2. Useful surface dry matter yield $\left(\mathrm{t} \mathrm{ha}^{-1}\right)$, phytomass utilization and energetic value Tabela 2. Prinos suve materije korisnih površina $\left(\mathrm{t} \mathrm{ha}^{-1}\right)$, iskorišćenje fitomase i energetska vrednost

\begin{tabular}{|c|c|c|c|c|}
\hline \multirow{2}{*}{$\begin{array}{l}\text { Regions } \\
\text { Regioni }\end{array}$} & \multicolumn{3}{|c|}{ Useful surface / Korisne površine } & \multirow{2}{*}{$\begin{array}{c}\mathrm{SU}^{*} \mathrm{~kg}^{-1} \\
\text { dry matter } \\
\text { suve materije }\end{array}$} \\
\hline & ha & $\mathrm{t} \mathrm{ha}^{-1}$ & $\begin{array}{c}\text { rate of phytomass } \\
\text { utilization } \\
\text { stopa iskorišćenja } \\
\text { fitomase }(\%)\end{array}$ & \\
\hline Shishtavec & 2,584 & 1.06 & 82 & 0.94 \\
\hline Gramoz & 3,723 & 1.16 & 77 & 0.93 \\
\hline Çajup & 2,013 & 0.89 & 83 & 1.04 \\
\hline Lenie & 3,124 & 0.85 & 80 & 0,84 \\
\hline Progonat & 2,474 & 0.78 & 83 & 0,98 \\
\hline Heremec-Delvine & 2,020 & 1.59 & 83 & 0,96 \\
\hline Dukaj & 2,144 & 0.71 & 67 & 1.15 \\
\hline
\end{tabular}

$* \mathrm{SU}=1420$ calories / kalorija 
optimum vegetation and the technical maturity for grazing $(8-10 \mathrm{~cm}$ for sheep and $12-15 \mathrm{~cm}$ for cattle). As a consequence, useful plants of meadows are highly thinned out. The results of the study show that the first grazing should begin between May 25 and June 10 for summer pastures, i.e. between March 20 and April 20 for winter pastures.

\section{Conclusions}

Albanian meadows are characterized by low yield per unit surface, different cycles of plant growth and seasonal vegetation of meadow plants.

Some meadows are not completely utilized, which is related to the techniques of grazing.

Complex measures such as establishment of the cultivated pasture, cleaning from solid materials, stones, scrubs and fertilization, sowing seeds in uncropped portions of meadows, irrigation, etc. must be implemented in order to increase the yield of meadows and their carrying capacities, as well as the lasting of grazing cycles.

Efficient and sustainable use of meadows could be achieved by a rational grazing by livestock. Two schemes of meadow utilization should be applied during the spring time while yield of meadows is abundant - harvesting one part of meadows and grazing the other part. If harvest is not possible, then meadows should only be grazed.

It is necessary to construct shelters and puddles on meadows to provide timely water supply to grazing livestock.

\section{References}

Bartels G B, Norton B E, Perrier G K (1993): An examination of the carrying capacity concept. In: R.H. Behnke, I. Scoones and C. Kerven (eds.): Range ecology at disequilibrium, overseas.

De Leeuw P N, Macdonald I A W (1994): Historical changes in stocking rates of domestic livestock as a measure of semiarid and arid rangeland degradation in the Cape province, South Africa. J. Arid Environ. 26: 281-298

Gilles J, Jamtgaard K (1981): Overgrazing in pastoral areas: the commons reconsidered. Sociologia Ruralis 21: 129-141

Herve D, Calagua D, Poupon H, Fernandes R (1989): Utilisation agropastorale du sol par les communautes du Haut Canete. Les Cahiers de la Recherche Development 24: 1-14

Hobbs N T, Swift D M (1985): Estimates of habitat carrying capacity incorporating explicit nutritional constraints. J. Wildl. Manage. 49: 814-822

Kuusela E, Khalili H (2002): Effect of grazing method and herbage allowance on the grazing efficiency of milk production in organic farming. Animal Feed Sci Technol. 98: 87-101

Lebaron A, Bond L K, Aitken P S, Michaelsen L (1979): An explanation of the Bolivian highlands grazing-erosion syndrome. J. of Range Management 32: 201-208

Macdonald K A, Penno J W, Lancaster J A S, Roche J R (2008): Effect of stocking rate on pasture production, milk production and reproduction of dairy cows in pasture-based systems. J. of Dairy Sci. 91: 2151-2163

Potvin F, Huot J (1983): Estimating carrying capacity of a white-tailed deer wintering area in Quebec. J. Wildl. Manage. 47: 463-475

Roe E M (1997): Viewpoint: On rangeland carrying capacity. Journal of range management 50: 467-472

Sinsin B (1993): Phytosociologie, ecologie, valeur pastorale, production et capacite de charge des paturages naturels du perimeter Nikki-Kalale au Nord-Beni; These presentee en vue de l'obtention du grade de docteur en Sciences Agronomiques; Universite libre de Bruxelles, Bruxelles

Steenekamp S J, Bosch O J H (1995): Construction and evaluation of condition assessment and grazing capacity models for use in grazing management in the Eastern mixed bushveld of Southern Africa. Journal of Arid Environments 30: 351-360

Shundi A, Buzi T (1991): Experimental results in improvement of mountainous pastures in Albania. Herbe 4: 50-52

\title{
Prinos i proizvodnost livada u Albaniji
}

\author{
Luan Hajno · Fikiri Tahiri
}

Centar za transfer poljoprivredne tehnologije u Fuše-Kruji, Albanija

Izvod: Ovo istraživanje je sprovedeno u periodu 2003-2005 na ukupnoj površini livada od 32.000 ha u sedam regiona Albanije (letnje livade Šištavec, Gramoz, Čajup, Lenije i Progonat i zimske livade Heremec-Delvine i Dukaj). Rezultati istraživanja su pokazali da je prosečan prinos suve materije letnjih livada nizak (oko $0,6 \pm 0,14 \mathrm{t} \mathrm{ha}^{-1}$ ) u rasponu od $0,33 \pm$ $0,07 \mathrm{t} \mathrm{ha}^{-1}$ do $0.53 \pm 0.10 \mathrm{tha}^{-1} \mathrm{za}$ siromašne livade (Progonat, Čajup, Lenije) i od 0,9 $\pm 0,17 \mathrm{tha}^{-1} \mathrm{do} 0,95 \pm 0,18 \mathrm{t} \mathrm{ha}^{-1} \mathrm{za}^{\mathrm{a}}$ bogate livade (Gramoz, Šištavec). Prinos suve materije zimskih livada kretao se u rasponu od 0,45 \pm 0,17 tha ${ }^{-1}$ (Dukaj) do $0,57 \pm 0,13 \mathrm{t} \mathrm{ha}^{-1}$ (Heremec-Delvine). Što se uopšteno tiče stope iskorišćenja travnate biomase, parcele bliže selima bile su preopterećene prevelikim brojem grla stoke, što je rezultiralo njihovom degradacijom. Koeficijent iskorišćenja travnate biomase je bio oko 94-95\% na livadama regiona Lenija i nekoliko drugih livada u blizini sela. Na nekoliko livadskih parcela (Lenia, Gramoz, Šištavec) koje su udaljene od sela i na velikoj nadmorskoj visini, koeficijent iskorišćenja livada je dostigao $50-60 \%$. Energetska vrednost izražena u jedinicama skroba (SU) zavisi od flore i uslova životne sredine. Prema laboratorijskim analizama, livade regiona Dukaj imale su najveće energetske vrednosti (oko 1,16 $\pm 0,22 \mathrm{SU} \mathrm{kg}^{-1}$ suve materije) dok su livade regiona Lenija imale najmanje energetske vrednosti (oko $0,84 \pm 0,16 \mathrm{SU} \mathrm{kg}^{-1}$ suve materije).

Ključne reči: parcela, prinos suve materije, proizvodnost livada, region, sitni preživari, uzorak 